\title{
Artificial Intelligence Techniques for Cancer Detection and Classification: Review Study
}

\author{
Alaá Rateb Mahmoud Al-shamasneh, PhD \\ Unaizah Hanum Binti Obaidellah, PhD
}

University of Malaya, Malysia

doi: 10.19044/esj.2016.v13n3p342 URL:http://dx.doi.org/10.19044/esj.2016.v13n3p342

\begin{abstract}
Cancer is the general name for a group of more than 100 diseases. Although cancer includes different types of diseases, they all start because abnormal cells grow out of control. Without treatment, cancer can cause serious health problems and even loss of life. Early detection of cancer may reduce mortality and morbidity. This paper presents a review of the detection methods for lung, breast, and brain cancers. These methods used for diagnosis include artificial intelligence techniques, such as support vector machine neural network, artificial neural network, fuzzy logic, and adaptive neuro-fuzzy inference system, with medical imaging like X-ray, ultrasound, magnetic resonance imaging, and computed tomography scan images. Imaging techniques are the most important approach for precise diagnosis of human cancer. We investigated all these techniques to identify a method that can provide superior accuracy and determine the best medical images for use in each type of cancer.
\end{abstract}

Keywords: Medical Imaging, Artificial Intelligence Techniques, Lung Cancer, Breast Cancer, Brain Cancer

\section{Introduction:}

Cancer is the name given to a group of related diseases. In all types of cancer, several body tissues start to divide without stopping and spread around cells. Cancer can start almost any place in the human body, which is composed of approximately trillions of cells. Human tissues normally grow and divide to form new tissues as the human body needs them. When cells age or become damaged, they die and are replaced with new cells. However, when cancer develops, this orderly process breaks down. As cells become increasingly abnormal, older or destroyed cells survive when they should die, and new cells form when they are not needed (Dalerba, Cho, \& Clarke, 2007). These extra cells can divide without stopping and may form growths 
called tumors. Numerous types of cancers form solid tumors, which are composed of cell masses. Cancers of the blood, such as leukemia's, often do not form solid tumors. Cancer tumors are malignant in which they can spread into, or invade, adjacent cells. A number of cancer tissues from these tumors can break off and go to distant areas in the body. New tumors can spread to areas away from the primary cancer growth through the blood or the lymph system. Benign tumors can often be removed, and in numerous instances, they do not go back and spread to other body parts. Cancer is a leading cause of disease worldwide. According to estimates from the International Agency for Research on Cancers, 14.1 million new cancer cases occurred and 8.2 million people died from cancer worldwide in 2012.(National Cancer Institute 2012)

\section{Computer-aided diagnosis (CAD) in medicine}

Manual classification of images is a challenging and time-consuming task. This task is highly susceptible to interobserver variability and human errors. Therefore, manual classification results in extremely poor critical outcomes, thus markedly increasing the workload of radiologists because of their significant shortage. In addition, medical care costs that are relevant to imaging rapidly increase (Cheng, Cai, Chen, Hu, \& Lou, 2003). New methods for diagnosis are therefore required. At present, CAD is one of numerous major research topics in diagnostic radiology and medical imaging(Murino, Puppo, Sona, Cristani, \& Sansone, 2015). The CAD approach helps medical doctors to diagnose diseases with a higher degree of efficiency, while minimizing examination time and cost, as well as avoiding unnecessary biopsy procedures. To date, CAD is a more suitable method for primary diagnosis of cancer, with the application of computed tomography (CT), X-ray, magnetic resonance imaging (MRI), or mammogram images (Doi, 2007). CAD is an effective intermediate between input images and the radiologist. The output from CAD is not considered as an end result; nevertheless, the result is used as reference with regard to additional testing in the related field.

The CAD assists medical doctors in early and more precise cancer detection. CAD may be developed in relation to more than one branch of knowledge, together with basic aspects of various areas, such as artificial intelligence (AI), image analysis, medical information processing and management, digital image processing, and pattern recognition (Murino et al., 2015). The CAD system is more reliable and efficient. The essential parameters of this system include specificity, sensitivity, and absolute detection rate.

- Specificity is also called the true negative rate. It measures the actual ratio of negatives that are correctly identified (Duncan et al., 2008). 
- Sensitivity is also called the true positive rate. It measures the actual ratio of positives that are correctly identified.(Fawcett, 2006)

The CAD system is often useful for breast, brain, lung, and other cancer types. Almost any part of the human body can be affected by cancer, which can spread to another body region. The CAD system has advanced considerably and achieved a high level of accuracy.

\section{Artificial Intelligence (AI)}

AI techniques are approaches that are utilized to produce and develop computer software programs. AI is an application that can re-create human perception. This application normally requires obtaining input to endow AI with analysis or dilemma solving, as well as the ability to categorize and identify objects. This paper describes various AI techniques, such as support vector machine (SVM) neural network, fuzzy models, artificial neural network (ANN), and K-nearest neighbor (K-NN). All methods are presented in (Fig. 1)

\section{Research Methodology}

Various intelligent techniques are utilized by researchers to help classify and segment medical image data to identify abnormalities within different areas of the body. This type of study is confined to the use of most of these techniques for classification and segmentation of medical image data.

\section{MEDICAL IMAGING}

Medical imaging has developed into a crucial part of earlier diagnosis, detection, and treatment method of cancer through the years. Medical imaging is usually the first step to avoiding the spread of cancer via earlier detection and, in numerous cases, assists in the treatment or total elimination of cancer. CT imaging, MRI, mammography, ultrasound (US) imaging, X-ray imaging, and so on, are typical imaging modalities used for fighting cancer, all of which are highlighted in (Fig. 2) 


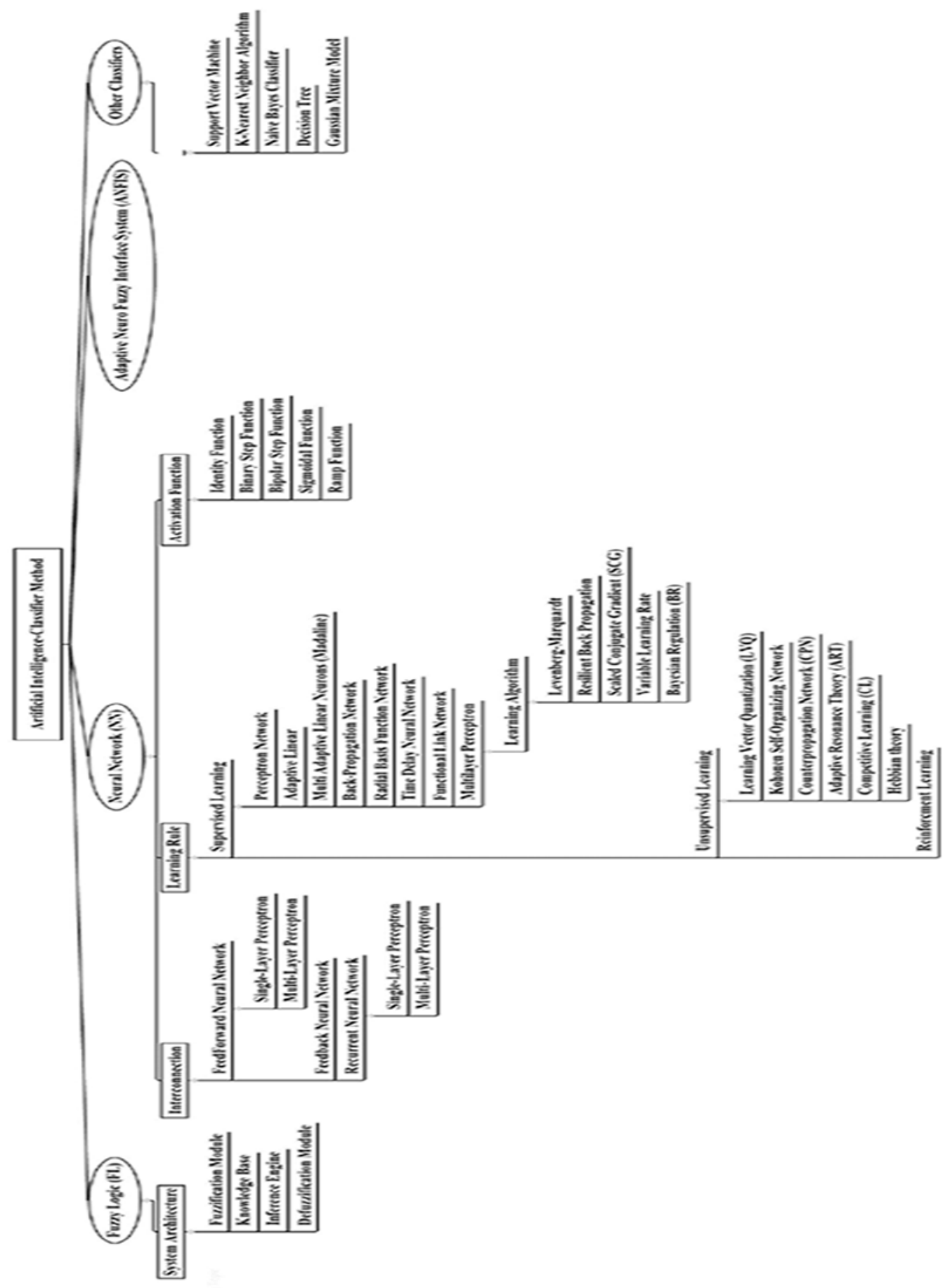

Figure .1. Various AI techniques in Image Processing 


\section{Diagnostic Images}
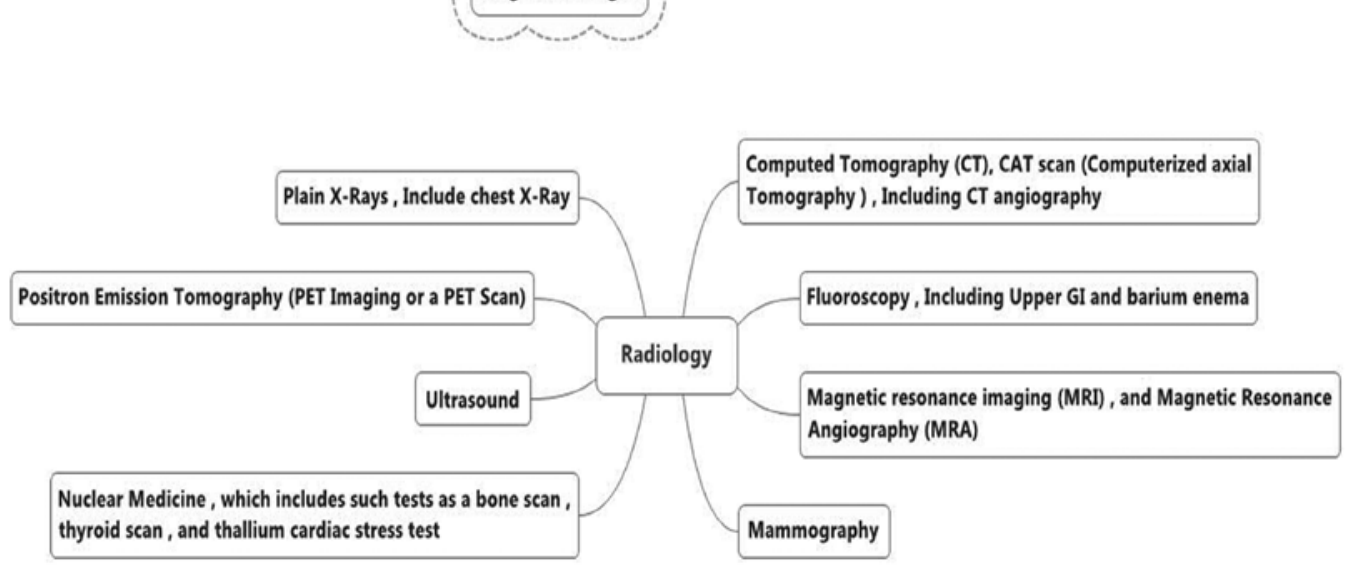

Figure 2. Different Types of Medical Images

\section{Classification of cancers}

Different types of AI algorithms are used to detect and classify different types of cancers. These techniques showed fluctuating accuracy across different years. This varying trend could be due to numerous factors, including network structure. In designing architecture for specific applications, the following selected parameters vary: network type, numbers of layers, number of nodes in hidden layers, activation function between layers, and the size of the dataset used (Dhokia, Kumar, Vichare, Newman, \& Allen, 2008), (Peng, Jianmin, \& Wu, 2009). Network generalization indicates how these networks are able to work with different data to decrease performance error to the lowest value.

\section{Breast Cancer}

Breast cancer is a malignant tumor that starts in the tissues of the breast. This cancer can expand directly into surrounding areas or maybe distribute to distant parts of the body. The disease occurs almost exclusively in females, but men can also develop this type of cancer (G. Schaefer et al., 2007).

With recent functions involving examinations, considerable interest with regard to the utilization of computational strategies to assist detection and diagnosis of breast cancer among most cancers is concentrated on mammography. The particular mammography technique is a simple yet effective tool for prognosis that involves breast cancer at an earlier stage (Cheng, Shan, Ju, Guo, \& Zhang, 2010). The Wisconsin Breast Cancer data (WBCD) source was offered by Dr. William H. Walberg, and the numerous AI techniques that are used by researchers and applied on WBCD database for prognosis, detection, and classification breast cancer are discussed in the 
succeeding paragraphs. This database, which is easily obtainable in the UCI database repository, contains 699 instances. (Lichman, (2013))

\section{Neural Network}

Different neural network algorithms use both supervised and unsupervised learning techniques for the diagnosis, prognosis, prediction, and classification of breast cancer through the years.

\section{Supervised techniques}

One supervised technique is the multi-layer perceptron (MLP). MLP can use different variant training methods, such backpropagation, scaled conjugate gradient, gradient descent, and Bayesian Regulation (BR) technique. Table 1 shows that (Jung, Thapa, \& Wang, 2005) used MLP with backpropagation training algorithms on Ultrasound (US) images, and (Swathi, Rizwana, Babu, Kumar, \& Sarma) employed MLP model and (BPNN). Both studies obtained high accuracies above 95\% for detecting and classifying breast cancer at 96.1\%, 95.74\%, and 99.28\%, respectively. However, (George, Elbagoury, Zayed, \& Roushdy, 2012) and (Raad, Kalakech, \& Ayache, 2012) obtained a low performance. George and Elbagoury used microscopic images collected from hospitals and obtained 80.66\% sensitivity and $76.28 \%$ specificity. Raad and Kalakech et al. obtained 88\% accuracy. (Azar \& El-Said, 2013), (Ubaidillah, Sallehuddin, \& Ali, 2013), and (Seema Singh 2014) used MLP with SCG learning algorithm, and they all obtained high accuracy of more than 95\%, with accuracies of 96.34\%, 98.54\%, and 97.47\%, respectively. (Janghel, Shukla, Tiwari, \& Kala, 2010) employed MLP with gradient descent and obtained a low accuracy of 51.88\%. By contrast, (B. K. Singh, Verma, \& Thoke, 2015) reported increased accuracy (84.6\%) with the use of the same technique on US images. Increased accuracy (97.51\%) was also obtained by (Seema Singh 2014) using MLP with different training methods, such as BR technique. (Al-Timemy, Al-Naima, \& Qaeeb, 2009), (George et al., 2012), (Swathi et al.) and (Azar \& El-Said, 2013) presented a PNN as a supervised classification technique. This technique exhibited a constantly increasing accuracy of more than 95\% from 2009 to 2013. (Janghel et al., 2010) used radial base function and obtained a low accuracy of 49.79\%. (Swathi et al.), (Azar \& El-Said, 2013), and (Raad et al., 2012) employed the same algorithm (RBF) and obtained the highest increasing accuracy of $96.18 \%$, 96.05\%, and 97\%, respectively. (Swathi et al.) examined general regression neural network and resulted in a high accuracy of $98.18 \%$ for breast cancer diagnosis. 
Unsupervised Technique

(Jung et al., 2005) applied linear vector quantization on US images, and (Janghel et al., 2010) used the same algorithm on different datasets; both studies obtained high accuracies (91.5\%, 95.82\%). By contrast, (George et al., 2012) obtained a low accuracy by employing the same algorithm on microscopic images collected from hospitals. A low accuracy (65\%) was also obtained by (Seema Singh 2014) with LVQ. (Jung et al., 2005) used US images, and (Seema Singh 2014) employed microscopic images. Both studies applied self-organization feature map technique, which yielded good accuracies of $87.9 \%$ and $84.45 \%$. (S. Singh, Saini, \& Singh, 2012) adopted ARNN technique and obtained an accuracy of $82.64 \%$, and (Janghel et al., 2010) used a competitive learning network and obtained a low accuracy of $74.48 \%$.

\section{ANFIS}

(Übeyli, 2009) and (Fatima \& Amine, 2012) used hybrid ANFIS technique with learning algorithms (backpropagation and least squares) and obtained high accuracies of 99.08\% and 98.25\%. (Fatima \& Amine, 2012) also used ANFIS with backpropagation algorithm and obtained a low accuracy of $64.91 \%$.

\section{Fuzzy Logic}

(R. Jain \& Abraham, 2004) applied rule generation based on homogeneous fuzzy sets and used another rule mean standard deviation of attribute values. (Al-Daoud, 2010) proposed a modified fuzzy c-means RBF network, and (Soria et al., 2013) adopted fuzzy algorithm linguistic rule. (GÖRGEL, SERTBAŞ, \& UÇAN, 2012) applied fuzzy subtractive ANFIS. (Onan, 2015) presented a hybrid intelligent fuzzy-rough nearest neighbor algorithm. All of these researchers used different fuzzy rules on mammogram data and obtained a high accuracy (>90\%) in detecting and classifying breast cancer.

(R. Jain \& Abraham, 2004) used rule generation based on a histogram of attribute values, and (Gerald Schaefer et al., 2007) proposed a system for breast cancer detection on thermography by using a fuzzy classification system (Miranda \& Felipe, 2014) presenting fuzzy omega algorithm method. Jain, Schaefer, and Miranda obtained good accuracy that exceeded $80 \%$ by using different fuzzy rules.

(R. Jain \& Abraham, 2004) applied a generation rule that depended on fuzzy partition of overlapping areas and obtained a low accuracy of $62.57 \%$. 
Other AI Classifier Techniques

(George et al., 2012) and (GÖRGEL et al., 2012) applied SVM and obtained more than $80 \%$ accuracy by using mammogram data collected from hospitals. (Ubaidillah et al., 2013) used the same technique and obtained a high accuracy of 99.51\%. (Jung et al., 2005) used K-means algorithms to classify breast cancer, yielding an accuracy of $87.4 \%$. Different changes were observed in accuracy over the years depending on numerous influencing factors, such as the used technique, dataset, network architecture, learning rate, epoch, and number of samples for training and testing. Numerous AI techniques can be used to diagnose breast cancer, yielding different accuracies by using different sources of data, such as mammograms, thermography, US, and microscopy. Effort has been expended to explore various AI techniques for detecting breast cancer. A comparative analysis is carried out to present all detection and classification methods, as shown in Table 1.

$\underline{\text { Results }}$

After evaluating the performance of different classifiers with respect to classifier accuracy, we will consider the highest classifier accuracy from each technique in all types of cancer.

\section{Breast Cancer}

(Fig.3) shows the highest accuracy values obtained from each technique for the detection and classification of breast cancer.

As shown in (Fig.3), FL using mammograms provides the best classifier technique for the detection and classification of breast cancer, yielding an accuracy of 99.73\% (R. Jain \& Abraham, 2004). FL can classify cancer cases with a high accuracy rate and is a powerful tool for decision making according to FL approval. In addition to adequate interpretability of extracted rules, the mathematical methods in fuzzy reasoning are simple, and FL can be modified by adding or even removing rules caused by the flexibility of FL methods. Despite the possibility of imprecise, altered noisy input information, FLS is easy to construct and understand (Cheng \& Cui, 2004).

The disadvantages of FL are generally the numerous probable fuzzy rules that exponentially increase with the dimensionality of pattern space (R. Jain \& Abraham, 2004) and the lack of systematic method for fuzzy system design. However, the method is easy to understand. The approach is simple and suitable for problems that do not require high accuracy.

The advantages of using breast screening mammograms are as follows. The approach minimizes the number of women who die of breast cancer. Breast screening can discover extremely small breast cancers before 
being sensed or observed and results in considerably better potential for survival as breast cancer can be found earlier with a screening mammogram. The leading threats for mammograms include non-ideal situations, in which normal breast cells can hide a breast cancer and thus will not appear on the mammogram. This finding is known as a false negative (Cheng et al., 2006).

As shown in (Fig.3), the K-NN applied on US images exhibited the lowest accuracy of $87.40 \%$ (Jung et al., 2005). The advantages for K-NN include extremely rapid training, ease and simplicity of understanding effective to noisy training data, and efficiency with usually large training data. The disadvantages include calculation complexity and memory space restriction. In addition, K-NN, a supervised learning lazy algorithm, runs slowly and is easily misled by unimportant attributes (Z. X. Huang, 1998).

In general, the results show the ability of different AI techniques to detect and classify breast cancer.

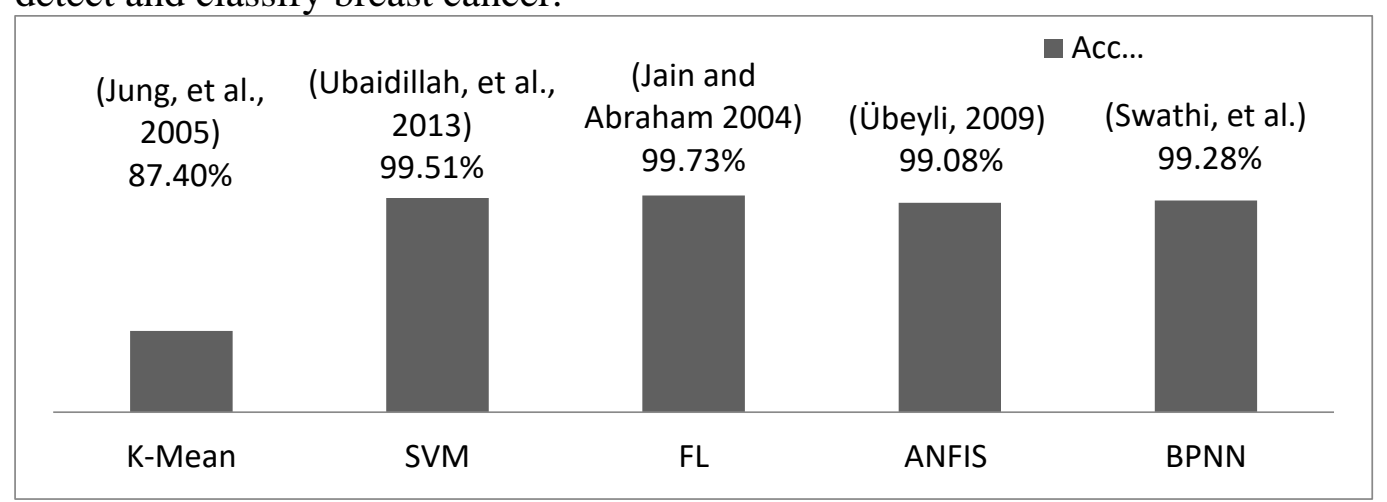

Figure .3. Performance Comparison of Different AI Techniques for Breast Cancer

Table 1. Summary of Breast Cancer Detection and Classification Works

\begin{tabular}{|c|c|c|c|c|c|c|c|c|}
\hline \multicolumn{9}{|c|}{ Breast Cancer } \\
\hline & $\begin{array}{l}\text { pe Of Network } \\
\text { sification Method }\end{array}$ & $\begin{array}{c}\text { Accura } \\
\text { cy }\end{array}$ & Sensitivity & $\begin{array}{c}\text { Precisio } \\
\mathrm{n}\end{array}$ & $\begin{array}{c}\text { Specificit } \\
\mathrm{y}\end{array}$ & Image Type & Reference & Year \\
\hline \multirow{4}{*}{ 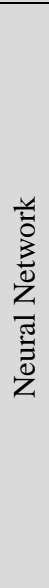 } & \multirow{4}{*}{$\begin{array}{l}\text { (MLP) Using } \\
\text { Backpropagation }\end{array}$} & $96.10 \%$ & NA & NA & NA & Ultrasound & $\begin{array}{c}\text { (Jung, } \\
\text { Thapa, \& } \\
\text { Wang, } \\
\text { 2005) }\end{array}$ & 2005 \\
\hline & & NA & $80.66 \%$ & NA & $76.28 \%$ & $\begin{array}{l}\text { Microscopic } \\
\text { Images }\end{array}$ & $\begin{array}{l}\text { (George, } \\
\text { Elbagoury, } \\
\text { Zayed, \& } \\
\text { Roushdy, } \\
\text { 2012) }\end{array}$ & 2012 \\
\hline & & $95.74 \%$ & NA & NA & NA & WBCD & $\begin{array}{c}\text { (Swathi, } \\
\text { Rizwana, } \\
\text { Babu, } \\
\text { Kumar, \& } \\
\text { Sarma) } \\
\end{array}$ & 2012 \\
\hline & & $88 \%$ & NA & NA & NA & WBCD & $\begin{array}{c}\text { (Raad, } \\
\text { Kalakech, \& }\end{array}$ & 2012 \\
\hline
\end{tabular}




\begin{tabular}{|c|c|c|c|c|c|c|c|}
\hline & & & & & & $\begin{array}{l}\text { Ayache, } \\
\text { 2012) }\end{array}$ & \\
\hline \multirow{3}{*}{$\begin{array}{l}\text { (MLP) Using } \\
\text { Scaled Conjugate } \\
\text { Gradient (SCG) }\end{array}$} & $96.34 \%$ & $97.07 \%$ & $97.29 \%$ & $94.98 \%$ & WBCD & $\begin{array}{l}\text { (Azar \& El- } \\
\text { Said, 2013) }\end{array}$ & 2013 \\
\hline & $98.54 \%$ & $99.25 \%$ & $97.22 \%$ & NA & WBCD & $\begin{array}{l}\text { (Ubaidillah, } \\
\text { Sallehuddin, } \\
\text { \& Ali, } \\
\text { 2013) }\end{array}$ & 2013 \\
\hline & $97.47 \%$ & $98.95 \%$ & NA & $96.09 \%$ & WBCD & $\begin{array}{c}\text { (Seema } \\
\text { Singh 2014) }\end{array}$ & 2014 \\
\hline \multirow{2}{*}{$\begin{array}{l}\text { (MLP) Using } \\
\text { Gradient Descent }\end{array}$} & $51.88 \%$ & NA & NA & NA & WBCD & $\begin{array}{c}\text { (Janghel, } \\
\text { Shukla, } \\
\text { Tiwari, \& } \\
\text { Kala, 2010) }\end{array}$ & 2010 \\
\hline & $84.60 \%$ & NA & NA & NA & Ultrasound & $\begin{array}{c}\text { (B. K. } \\
\text { Singh, } \\
\text { Verma, \& } \\
\text { Thoke, } \\
\text { 2015) }\end{array}$ & 2015 \\
\hline $\begin{array}{c}\text { Multi-Layer } \\
\text { Feedforward } \\
\text { Network USING } \\
\text { Bayesian } \\
\text { Regularization } \\
\text { based } \\
\text { Backpropagation } \\
\end{array}$ & $97.51 \%$ & $96 \%$ & NA & $99.12 \%$ & WBCD & $\begin{array}{c}\text { (Seema } \\
\text { Singh 2014) }\end{array}$ & 2014 \\
\hline $\begin{array}{c}\text { Backpropagation } \\
\text { Neural Network } \\
\text { (BPNN) }\end{array}$ & $99.28 \%$ & NA & NA & NA & WBCD & $\begin{array}{c}\text { (Swathi et } \\
\text { al.) }\end{array}$ & 2012 \\
\hline $\begin{array}{l}\text { Adaptive Resonance } \\
\text { Neural Network } \\
\text { (ARNN) }\end{array}$ & $82.64 \%$ & $75 \%$ & $79 \%$ & NA & WBCD & $\begin{array}{l}\text { (S. Singh, } \\
\text { Saini, \& } \\
\text { Singh, } \\
\text { 2012) }\end{array}$ & 2012 \\
\hline \multirow{4}{*}{$\begin{array}{c}\text { Radial Basis } \\
\text { Function (RBF) }\end{array}$} & $49.79 \%$ & NA & NA & NA & WBCD & $\begin{array}{l}\text { (Janghel et } \\
\text { al., 2010) }\end{array}$ & 2010 \\
\hline & $96.18 \%$ & NA & NA & NA & WBCD & $\begin{array}{c}\text { (Swathi et } \\
\text { al.) }\end{array}$ & 2012 \\
\hline & $97 \%$ & NA & NA & NA & WBCD & $\begin{array}{c}\text { (Raad et al., } \\
\text { 2012) }\end{array}$ & 2012 \\
\hline & $96.05 \%$ & $96.62 \%$ & $97.28 \%$ & $94.98 \%$ & WBCD & $\begin{array}{l}\text { (Azar \& El- } \\
\text { Said, 2013) }\end{array}$ & 2013 \\
\hline \multirow{2}{*}{$\begin{array}{l}\text { Self-Organization } \\
\text { Map (SOM) }\end{array}$} & $87.90 \%$ & NA & NA & NA & Ultrasound & $\begin{array}{c}\text { (Jung et al., } \\
2005)\end{array}$ & 2005 \\
\hline & $84.45 \%$ & NA & NA & NA & WBCD & $\begin{array}{c}\text { (Seema } \\
\text { Singh 2014) }\end{array}$ & 2014 \\
\hline \multirow{3}{*}{$\begin{array}{c}\text { Linear Vector } \\
\text { Quantization (LVQ) }\end{array}$} & $91.50 \%$ & NA & NA & NA & Ultrasound & $\begin{array}{c}\text { (Jung et al., } \\
\text { 2005) }\end{array}$ & 2005 \\
\hline & $95.82 \%$ & NA & NA & NA & WBCD & $\begin{array}{l}\text { (Janghel et } \\
\text { al., 2010) }\end{array}$ & 2010 \\
\hline & NA & $87.95 \%$ & $85.69 \%$ & NA & $\begin{array}{l}\text { Microscopic } \\
\text { Images }\end{array}$ & $\begin{array}{l}\text { (George et } \\
\text { al., 2012) }\end{array}$ & 2012 \\
\hline
\end{tabular}




\begin{tabular}{|c|c|c|c|c|c|c|c|c|}
\hline & & $65 \%$ & NA & NA & NA & WBCD & $\begin{array}{c}\text { (Seema } \\
\text { Singh 2014) }\end{array}$ & 2014 \\
\hline & \multirow{4}{*}{$\begin{array}{l}\text { Probabilistic Neural } \\
\text { Network (PNN) }\end{array}$} & $96.20 \%$ & $97.50 \%$ & NA & $92.50 \%$ & WBCD & $\begin{array}{c}\text { (Al- } \\
\text { Timemy, } \\
\text { Al-Naima, } \\
\text { \& Qaeeb, } \\
\text { 2009) }\end{array}$ & 2009 \\
\hline & & NA & $96.32 \%$ & $94.57 \%$ & NA & $\begin{array}{c}\text { Microscopic } \\
\text { Images } \\
\end{array}$ & $\begin{array}{c}\text { (George et } \\
\text { al., 2012) }\end{array}$ & 2012 \\
\hline & & $97.00 \%$ & NA & NA & NA & WBCD & $\begin{array}{c}\text { (Swathi et } \\
\text { al.) }\end{array}$ & 2012 \\
\hline & & $97.66 \%$ & $98.65 \%$ & $97.77 \%$ & $95.82 \%$ & WBCD & $\begin{array}{l}\text { (Azar \& El- } \\
\text { Said, 2013) }\end{array}$ & 2013 \\
\hline & $\begin{array}{c}\text { General Regression } \\
\text { Neural Network } \\
\text { (GRNN) }\end{array}$ & $98.18 \%$ & NA & NA & NA & WBCD & $\begin{array}{l}\text { (Swathi et } \\
\text { al.) }\end{array}$ & 2012 \\
\hline \multirow{3}{*}{ 至 } & $\begin{array}{c}\text { Least Squares } \\
\text { Method + Gradient } \\
\text { Descent }\end{array}$ & $99.08 \%$ & $98.74 \%$ & NA & $99.27 \%$ & WBCD & $\begin{array}{l}\text { (Übeyli, } \\
\text { 2009) }\end{array}$ & 2009 \\
\hline & $\begin{array}{c}\text { Backpropagation } \\
\text { +Least Squares For } \\
\text { learning }\end{array}$ & $98.25 \%$ & $97.50 \%$ & NA & $98.65 \%$ & WBCD & $\begin{array}{l}\text { (Fatima \& } \\
\text { Amine, } \\
\text { 2012) }\end{array}$ & 2012 \\
\hline & Backpropagation & $64.91 \%$ & $0 \%$ & NA & $100 \%$ & WBCD & $\begin{array}{l}\text { (Fatima \& } \\
\text { Amine, } \\
\text { 2012) }\end{array}$ & 2012 \\
\hline \multirow{9}{*}{ 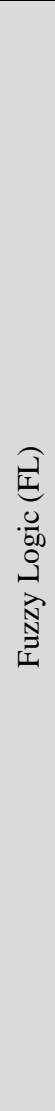 } & $\begin{array}{c}\text { Homogeneous } \\
\text { Fuzzy }\end{array}$ & $99.73 \%$ & NA & NA & NA & WBCD & $\begin{array}{c}\text { (Jain \& } \\
\text { Abraham, } \\
\text { 2004) }\end{array}$ & 2004 \\
\hline & $\begin{array}{l}\text { Mean and Standard } \\
\text { Deviation of } \\
\text { attributes values }\end{array}$ & $92.20 \%$ & NA & NA & NA & WBCD & $\begin{array}{l}\text { (Jain \& } \\
\text { Abraham, } \\
\text { 2004) }\end{array}$ & 2004 \\
\hline & $\begin{array}{c}\text { Histogram attributes } \\
\text { value }\end{array}$ & $86.70 \%$ & NA & NA & NA & WBCD & $\begin{array}{l}\text { (Jain \& } \\
\text { Abraham, } \\
\text { 2004) }\end{array}$ & 2004 \\
\hline & $\begin{array}{l}\text { Fuzzy Partition of } \\
\text { overlapping areas }\end{array}$ & $62.57 \%$ & NA & NA & NA & WBCD & $\begin{array}{c}\text { (Jain \& } \\
\text { Abraham, } \\
\text { 2004) }\end{array}$ & 2004 \\
\hline & $\begin{array}{c}\text { Fuzzy Classification } \\
\text { System }\end{array}$ & $80 \%$ & NA & NA & NA & $\begin{array}{c}\text { Thermograph } \\
\mathrm{y}\end{array}$ & $\begin{array}{l}\text { (Schaefer et } \\
\text { al., 2007) }\end{array}$ & 2007 \\
\hline & $\begin{array}{l}\text { Modified Fuzzy C- } \\
\text { Means Radial Basis } \\
\text { Function (MFRBF) }\end{array}$ & $97 \%$ & NA & NA & NA & WBCD & $\begin{array}{l}\text { (Al-Daoud, } \\
\text { 2010) }\end{array}$ & 2010 \\
\hline & $\begin{array}{l}\text { Fuzzy Algorithm } \\
\text { Linguistic Rule }\end{array}$ & $95 \%$ & NA & NA & NA & $\begin{array}{c}\text { distinct } \\
\text { clinical } \\
\text { phenotypes(gr } \\
\text { oups) using } \\
\text { immune } \\
\text { histochemical } \\
\text { analysis } \\
\end{array}$ & $\begin{array}{l}\text { (Soria et al., } \\
\text { 2013) }\end{array}$ & 2013 \\
\hline & $\begin{array}{l}\text { fuzzy Omega } \\
\text { Algorithm }\end{array}$ & $83.34 \%$ & NA & NA & NA & $\begin{array}{c}\text { Digital } \\
\text { Database for } \\
\text { Screening } \\
\text { Mammograph } \\
\text { y (DDSM) } \\
\end{array}$ & $\begin{array}{l}\text { (Miranda \& } \\
\text { Felipe, } \\
\text { 2014) }\end{array}$ & 2014 \\
\hline & Fuzzy Subtractive & $92 \%$ & $100 \%$ & $86 \%$ & $86 \%$ & Mammogram' & (GÖRGEL, & 2012 \\
\hline
\end{tabular}




\begin{tabular}{|c|c|c|c|c|c|c|c|c|}
\hline & ANFIS & & & & & $\mathrm{s}$ & $\begin{array}{c}\text { SERTBAŞ, } \\
\text { \& UÇAN, } \\
\text { 2012) }\end{array}$ & \\
\hline & $\begin{array}{c}\text { Fuzzy-Rough } \\
\text { Nearest Neighbor } \\
\text { Algorithm } \\
\end{array}$ & $99.72 \%$ & NA & NA & NA & Mammograms & $\begin{array}{l}\text { (Onan, } \\
\text { 2015) }\end{array}$ & 2015 \\
\hline \multirow{4}{*}{ 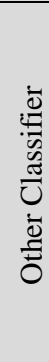 } & \multirow{3}{*}{ SVM } & NA & $88.48 \%$ & $90.99 \%$ & NA & $\begin{array}{c}\text { Microscopic } \\
\text { Images } \\
\end{array}$ & $\begin{array}{c}\text { (George et } \\
\text { al., 2012) }\end{array}$ & 2012 \\
\hline & & $99.51 \%$ & $99.25 \%$ & $100 \%$ & NA & WBCD & $\begin{array}{l}\text { (Ubaidillah } \\
\text { et al., 2013) }\end{array}$ & 2013 \\
\hline & & $88 \%$ & $92 \%$ & $86 \%$ & $85 \%$ & $\begin{array}{c}\text { Mammogram' } \\
\text { s }\end{array}$ & $\begin{array}{l}\text { (GÖRGEL } \\
\text { et al., 2012) }\end{array}$ & 2012 \\
\hline & K-NN & $87.40 \%$ & NA & NA & NA & Ultrasound & $\begin{array}{c}\text { (Jung et al., } \\
\text { 2005) }\end{array}$ & 2005 \\
\hline & NEIS dantiven & $\begin{array}{l}\text { fuzzy inf } \\
\text { Machines }\end{array}$ & $\begin{array}{l}\text { ce syst } \\
\text { M) }\end{array}$ & $\begin{array}{r}\text { MLP, } \\
\text { K-NN, K }\end{array}$ & Lay & $\begin{array}{l}\text { eptron } \\
\text { s algorithm }\end{array}$ & M ,Support V & tor \\
\hline
\end{tabular}

Lung Cancer

Lung cancer can include out-of-control development associated with unnatural tissues, which start in a single or even the two lungs. The unusual cells generally do not grow into healthy lung cells, instead separating rapidly and forming cancers. Major types of lung cancer usually involve non-small cell and small cell lung cancer. These cancers depend on how tissues appear under a microscope. Non-small cell lung cancer is more widespread compared with small-cell lung cancer (C. Zhou et al., 2011). Lung cancer is probably the type that commonly leads to extremely high death rate. The most effective method of protection against lung cancer is early prediction and diagnosis. Detection of lung cancer at an early stage is a complicated issue because of the construction on cancer tissues, in which almost all cells are overlapped. Besides being a crucial element in image processing, efficient identification of lung cancer at an initial stage is usually important.

Numerous techniques, including $\mathrm{CT}$, chest radiography (X-ray), sputum cytology, and MRI scan, are used to diagnose lung cancer. However, several of these techniques are usually expensive. Many of these methods are not only time consuming butalso often detect lung cancer in the advanced phases, relatively decreasing the patient's chance of survival. New technologies to aid the diagnosis of lung cancer at the initial stage is necessary. Image processing and data mining methods provide good quality tools for enhancing manual analysis.

\section{Neural Networks}

(Z.-H. Zhou, Jiang, Yang, \& Chen, 2002) proposed a lung cancer diagnosis system named LCDS to identify lung cancer cells through the images of needle biopsy specimens. In this system, neural ensemble-based 
detection (NED) with two-level ensemble architecture is used to accomplish its task. The NED achieves high overall identification rate and low rate falsenegative identification, whereas LCD needs to improve performance in dealing with overlapped cells.(Pereira, Alexandre, Mendonça, \& Campilho, 2006) examined a classification approach for the lung nodule in X-ray chest radiographs. The multi classifier (MLP) approach and the obtained results can be used for reducing false-positive nodules. (Nehemiah \& Kannan, 2006) proposed a system that uses image processing and feedforward neural networks to detect and classify lung nodules into non-cancerous and cancerous nodules and he success in that .

(Taher \& Sammouda, 2011) presented Hopfield neural network (HNN) and fuzzy C-mean (FCM) for detection of lung cancer in the early stages as a segmentation method. One thousand sputum color images are used for the approach. HNN is more successful in extracting the nuclei and cytoplasm regions than FCM, which detects only one part. However, FCM is not sensitive to intensity variations. For solving the problem of applied threshold and detecting nuclei and cytoplasm regions, overall thresholding exhibits a high accuracy of $98 \%$.

Bayesian classification and HNN algorithm (Taher, Werghi, \& AlAhmad, 2012) are presented for extracting and segmenting the sputum cells for early lung cancer diagnosis, and 88.62\% accuracy was obtained.

(Ada $\left.{ }^{1}, 2013\right)$ used a two-method preprocessing and a feed-forward BPNN classifier to detect and classify lung cancer at the early stages. The neural network achieved correct classification, with the highest rate of 96.4\%. (Kuruvilla \& Gunavathi, 2014) presented feedforward and feedforward BPNN as a classification method for lung nodule detection through CT images. Feedforward back-propagation results in superior classification and is based on the rear-correction learning rule. Feedforward backpropagation obtained an accuracy of $93.3 \%$ and a minimum mean square error of 0.0942. In addition, the parameter skewness and training function yield the maximum accuracy. (Gorynski et al., 2014) presented an MLP for the detection and diagnosis of lung cancer at an early stage.

Neural networks achieved high accuracy of more than $95 \%$ in detecting and classifying lung nodules.

\section{$\underline{\mathrm{FL}}$}

(Hashemi, Pilevar, \& Rafeh, 2013) proposed a model for lung cancer diagnosis at the early stages through CT images. The model yielded 95\% sensitivity. Segmentation and decision-making were conducted using FIS, and an ANN was used to test the result. (Memarian, Alirezaie, \& Babyn, 2006) proposed an iterative linear discriminant analysis as a novel classification method and used this method in addition to FCM clustering for 
successful false-positive reduction. The sensitivity of this approach was $80.80 \%$.

\section{ANFIS}

(Tariq, Akram, \& Javed, 2013)proposed a hybrid neuro-fuzzy classifier as an effective computerized system for lung nodule detection using CT scan images. The approach yielded 95\% accuracy.

\section{Other classifiers}

(Song, Zhukov, Markov, Qian, \& Tockman, 2012) proposed a system for classifying lung cancer by using SVM and linear discriminant analysis with 10 -fold cross validation and obtained an accuracy of 85\%.

(Madero Orozco, Vergara Villegas, de Jesus Ochoa Dominguez, \& Cruz Sanchez, 2013) developed simple and effective methods for classifying lung cancer without a segmentation stage to classify the used lung cancer SVM. These methods resulted in 84\% accuracy. (Sivakumar \& Chandrasekar, 2013) presented an effective scheme for detecting lung cancer by performing nodule segmentation. Classification SVM was used for this approach, and an accuracy of $80.36 \%$ was obtained. Based on the above results, SVM is used to classify lung tissues through CT images and yields good accuracy above 80\%. (Kanakatte, Mani, Srinivasan, \& Gubbi, 2008) presented an automated process that uses K-NN and SVM classifier to analyze performance for volume and tumor delineation features from PET lung images and obtained a high accuracy of 97\%. SVM yields high accuracy with PET lung images compared with CT images. Comparative analysis was carried out for presenting all detection and classification methods, as shown in Table 2.

\section{$\underline{\text { Result }}$}

We take the highest classifier accuracy from each technique. Figure 4 shows the accuracy for lung cancer detection and classification as follows.

(Fig.4) shows that the most accurate result (i.e., 96.04\%) for CT scan is achieved using the feedforward backpropagation (Ada 1 , 2013). Feedforward neural networks that are capable of classifying cancer cases with high accuracy rate have become an effective tool. Computation time is fixed, and extremely high computation speed results from the parallel structure. Moreover, the approach is fault-tolerant because of the distributed nature of network knowledge. General solutions can be learned from presented training data. Neural networks eliminate the requirement to produce an explicit model of a process. Moreover, these networks can easily model parts of a process that cannot be modeled or even usually unidentified. A neural network could learn from incomplete and noisy data, but the 
solution may be less precise. The capability to generalize situations is not trained to the network previously (G. B. Huang, Chen, \& Siew, 2006).

Similar with any method, neural networks present specific disadvantages. As neural networks find a general approximation of a solution, smaller error is generally associated with neural network results. The complete nature of neural networks is not completely understood; therefore, it is proposed that future research should consider an experimental method to assess the issue of efficiency. At present, no neural network computers available at a reasonable cost are available. Moreover, neural network errors vary based on the architecture. Finally, neural networks require long training periods. The use of CT images for detecting lung cancer offers numerous advantages. Small nodules in lung cancer can be simply identified using CT tests, and chest CT is particularly efficient for diagnosing lung cancer in the early stages, or the nearly curable phase. Issues identified with CT screening include false-positive scans, diagnosis of benign nodule resections, influence of radiation, and cost. As low dose CT has been proven to minimize mortality, the issues of CT screening are recognized as manageable, with the possible exception of cost (Gould et al., 2013). With PET images, greater accuracy of $97 \%$ is accomplished through the use of the SVM classifier (Kanakatte et al., 2008). Numerous advantages of SVMs include efficiency with high-dimensional spaces, maintained efficiency even when the number of dimensions exceeds the sample number, and memory efficiency owing to the use of a subset of training points in the decision function (called support vector). Versatility: various kernel functions can be specified for the decision function. Different kernels, such as polynomial or linear kernels, can be utilized in SVM models, but custom kernels can also be used for specification. Several advantages for using SVM in detecting and classifying lung cancer are available, but certain disadvantages are also present. When the amount of features is markedly higher than the number of samples, the technique will probably provide weak performance. SVMs do not immediately offer probability estimates; SVMs are computed using a costly fivefold cross-validation.

PET imaging is unique, displaying the actual chemical function, involving tissues and organs. Through various other imaging methods, such as MRI and CT display structure, improved accurate attenuation correction and sensitivity can be supplied by the PET imaging modality. The drawbacks of the approach include the use of ionizing radiation, high cost and rarity, care in using radio-nuclides, and poor resolution.

ZeroR classifier, which possesses the lowest accuracy of 53.30\%, can be the simplest classification technique that depends upon the target and disregards all predicators. The ZeroR classifier simply predicts almost all classification classed. Despite the lack of predictability power in ZeroR, the 
classifier is helpful in determining a baseline efficiency, such as a benchmark intended for other classification techniques.

(Taher, Werghi, \&

\section{(Kanakatte, Mani,}

Al-Ahmad, 2012

Srinivasan, \& (Tariq, Akrram,":\&

$88.62 \%$

Ada', 2013)(Ada', 201Gubbi, 2008)

$\begin{array}{cc}\text { Javed, 2013) } & \left(\mathrm{Ada}^{1}, 2013\right) \\ 96.00 \% & 96.04 \%\end{array}$

$63.44 \%$

$53.30 \%$

$95.00 \%$
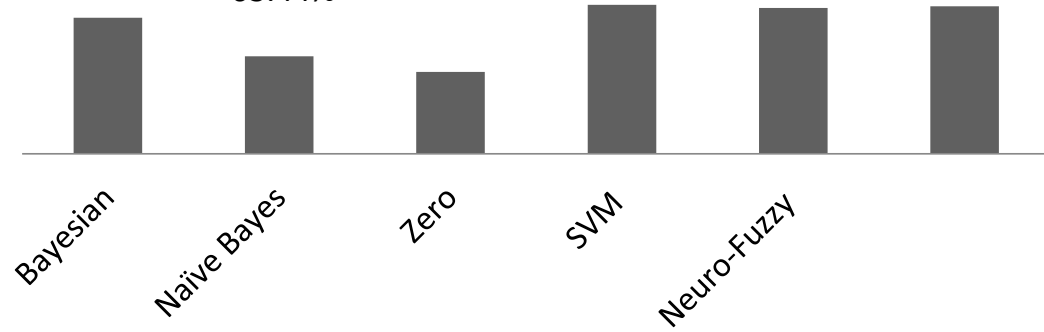

Figure .4. Performance Comparison of different AI Techniques for Lung Cancer

Table 2. Summary of Lung Cancer Detection and Classification Works

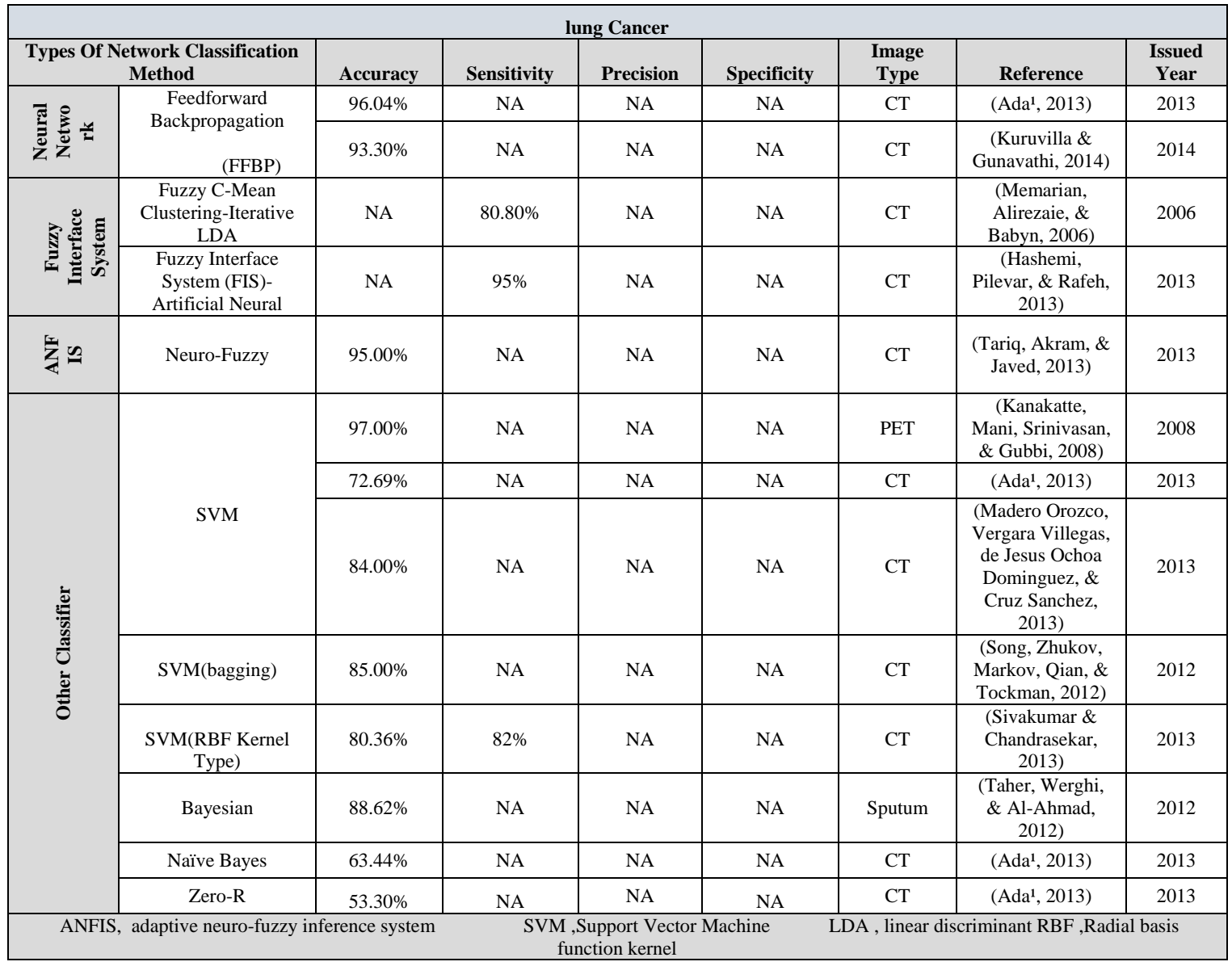




\section{Brain Cancer}

The central nervous system includes the brain and spinal cord. Brain tumor is probably the major driving force behind death occurrence from cancer. Brain tumors are also known as gliomas and meningioma. Two essential types of brain tumor include brain cancer and tumors that start in the brain. Cancer cells can spread and enter healthy cells in the brain and spinal cord but not often spread to other body parts. Secondary brain tumor is a more common type. The cancer begins within a different part of the human body, like lung cancer or breast cancer, and spreads to the brain. This tumor is known as a metastatic brain tumor. Brain cancer is likely curable and treatable if detected at the initial stages of the disease. Without treatment, brain tumors can spread and cause death. Various methods are used for obtaining images of human brain. These types of methods include X-ray, CT, electroencephalogram (EEG) signal, and MRI. These methods are used for diagnosis.

\section{ANN}

\section{$\underline{\text { Supervised }}$}

(Ibrahim, Osman, \& Mohamed, 2013; S. Jain \& Mishra; Mahajani), and (Kharat, Kulkarni, \& Nagori, 2012) presented a system for the diagnosis and classification of brain tumor from MRI images by using a backpropagation network and obtained different accuracy rates. Jain and Mahajani obtained accuracies of $77.56 \%$ and $72.5 \%$, whereas Ibrahim obtained $96.33 \%$. The differences in accuracy could be due to the different dataset used. Therefore, different features are extracted, such as the number of images that Ibrahim used was more than that of Jain and Mahjani. In addition, the neural network architecture and learning algorithms are different.(Karameh \& Dahleh, 2000) developed a system to identify brain cancer by using EEG signals with a multi SOM. (Al-Naami, Mallouh, \& Hafez, 2014)proposed multi-layer feedforward neural networks algorithms using MRI images and obtained accuracy rate of 86.9\%. (S. Jain \& Mishra, 2013), (Sapra, Singh, \& Khurana, 2013), (SubbaRao, Revanth, \& UdayKumar, 2013), and (Othman \& Basri, 2011) presented a system as a diagnostic tool to identify brain tumor from MRI imaging by using PNN. Jain and Sapra obtained a high accuracy rate (98.08\% and 100\%). (Al-Naami et al., 2014) proposed neural network methods for classifying brain tumor from MRI images, and both techniques obtained a high accuracy rate. NARX neural network obtained 99.1\% accuracy, and Elman obtained 98.1\% accuracy. (Mahmood \& Abd-Alsalam, 2014) presented a classification technique for identifying brain tumor from MRI images. A classification process was initially performed using a FIS, followed by feedforward neuralnetwork. The hybrid method yielded a high accuracy of $95.66 \%$. 


\section{Unsupervised}

(Hemanth, Anitha, \& Balas, 2015) and (Goswami \& Bhaiya, 2013) presented an unsupervised learning-based neural network to classify brain tumor from MRI human brain images. Both presented an accuracy of more than 95\%. Hemanth proposed a hybrid classification system that combines practical swarm optimization and Kohonen neural network. The system achieved 95\% accuracy. Goswami used SOM, and 98.6\% change was achieved using this method.

\section{ANFIS}

Numerous studies have adopted the ANFIS method (Darvishi \& AlAni, 2007; Joshi, Rana, \& Misra, 2010) for detecting and classifying brain cancer. (Hemanth, Vijila, \& Anitha, 1995) and (Al-Naami et al., 2014) proposed the ANFIS system for brain tumor classification from MRI images by using backpropagation and least-squares technique. For training algorithms, the accuracies were $93.3 \%$ and $89.7 \%$, respectively; these results were obtained using different datasets, ANN architecture, and number of training. Testing samples of all these factors could explain the decreasing accuracy in 2014. (Malakooti, Mousavi, \& Taba, 2013), (Deshmukh \& Khule, 2014), and (Kumar \& Kumar, 2008)) proved that ANFIS with backpropagation learning algorithm exhibited good accuracy on segmented MRI image tumors. Malakooti obtained an accuracy rate of 89.1\%. Identical ANFIS techniques and data image type (MR) are used for the detection and classification of brain tumor, but the use of different training algorithms (gradient descent and backpropagation) yielded better accuracy of more than 90\%.(Sharma, 2012), (Bhardwaj \& Siddhu) and (Basri, Othman, \& Husain, 2013) proposed Gradient Descent and Backpropagation algorithms and obtained accuracy rates of 98.67\%, 94\%, and 94.67\%, respectively.

$\underline{F L}$

Numerous studies have been conducted on the detection and classification of brain cancer through FL. (Padmapriya \& Maragatham, 2013), (Dasgupta, 2012), (Anandgaonkar \& Sable, 2013), and (Fazel Zarandi, Zarinbal, \& Izadi, 2011) agreed that FL is an effective tool.

\section{Other Classifiers}

In this paper ,(Zacharaki et al., 2009) used SVM for classifying brain tumor from mixedperfusion (MRI), and the accuracy was $87 \%$. (Dhanalakshmi \& Rajamani, 2013) showed a fuzzy support vector (fuzzy SVM) to enhance diagnosis using CT scan brain images. The results show that the method achieves good accuracy of up to $88 \%$. A new step-wise procedure was proposed by (Karuppathal \& Palanisamy, 2006) for detecting 
and classifying brain cancer in MRI image. In this procedure, a fuzzy-KNN classifier was used with the MRI images, and the resulting accuracy from this approach was 99\%. In a different research,(Mahajani) developed a system for classifying and detecting brain tumor from MRI images with KNN and 70\% accuracy was achieved. (Hiran \& Doshi, 2013; Joshi et al., 2010; Kathalkar, Kawitkar, \& Chopade, 2013), (Madhusudhanareddy \& Prabha, 2013; Nalbalwar, Majhi, Patil, \& Gonge) proposed a system for detecting and classifying brain tumor from MRI images using ANN algorithm for various affected people. Different image processing methods, such as image segmentation, histogram equalization image enhancement, morphological operation, and feature extraction, are used (Joshi et al., 2010). A comparative analysis was carried out to present all detection and classification methods, as shown in Table 3.

\section{$\underline{\text { Result }}$}

We take the highest classifier accuracy from each technique. (Fig.5) shows the accuracy for the detection and classification of brain cancer as follows.

As shown in (Fig.5), the most accurate result, that is, 100\%, is achieved using PPN, which (Sapra et al., 2013) approved to be a powerful tool. This technique can classify brain cancer cases with high accuracy rate. Several advantages for using PNN include the rapid training process, inherently parallel structure, insensitivity to outliers, and the ability to compute nonlinear decision boundaries, and the possibility of addition or removal of training samples without extensive retraining. Contrary to those advantages, the disadvantages for PNN include large memory requirements, a representative training set, and slow execution of network when classifying new cases. MRI has developed into a widespread, high-quality medical imaging. Especially within brain imaging, MRI is helpful for scanning and detecting abnormalities within soft tissue structures. MRI provides an unparalleled view inside the human body and is utilized mainly in medical settings to provide high quality images inside the human body. The amount of details is considerable with the use of another imaging modality.

Any type of radiation is not involved in the MRI. Several disadvantages of using MRI include the scanning noise because of operator performance, which can cause serious inaccuracies in classification, and the high cost of MRI scanners.

K-NN applied on MRI images presented the lowest accuracy of $70 \%$. K-NN classification rule (Mahajani) is one of the most well-known and widely used nonparametric pattern classification method. K-NN is a simple supervised classifier that provides good efficiency for optimal values of $K$. Moreover, in K-NN, training is extremely fast and any learning task is easy. 
In addition, the approach is effective for noisy training data and efficient with large training data. Disadvantages of this approach include computation complexity and memory limitation. In addition, as a supervised learning lazy algorithm, K-NN runs slowly and is easily misled by irrelevant attributes.

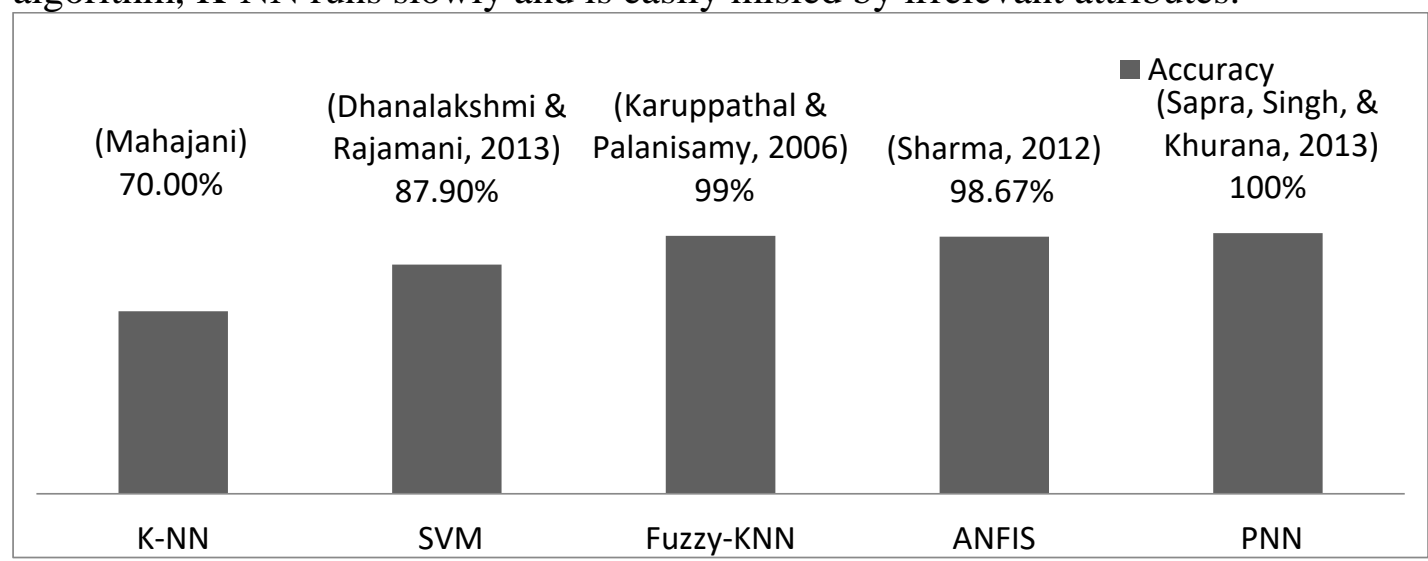

Figure .5. Performance Comparison of different AI Techniques for Brain Cancer

Table 3. Summary of Brain Cancer Detection and Classification Works

\begin{tabular}{|c|c|c|c|c|c|c|c|c|}
\hline \multicolumn{9}{|c|}{ Brain Cancer } \\
\hline \multicolumn{2}{|c|}{$\begin{array}{c}\text { Types Of Network } \\
\text { Classification Method }\end{array}$} & Accuracy & Sensitivity & Precision & Specificity & Image Type & Reference & $\begin{array}{l}\text { Issued } \\
\text { Year }\end{array}$ \\
\hline \multirow{11}{*}{ 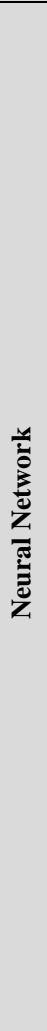 } & \multirow{3}{*}{$\begin{array}{l}\text { Backpropagation } \\
\text { Artificial Neural } \\
\text { Network(BPNs) }\end{array}$} & $77.56 \%$ & NA & NA & NA & MRI & $\begin{array}{l}\text { (Jain \& } \\
\text { Mishra) }\end{array}$ & 2013 \\
\hline & & $96.33 \%$ & NA & NA & NA & MRI & $\begin{array}{l}\text { (Ibrahim, } \\
\text { Osman, \& } \\
\text { Mohamed, } \\
\text { 2013) }\end{array}$ & 2013 \\
\hline & & $72.50 \%$ & NA & NA & NA & MRI & (Mahajani) & 2013 \\
\hline & $\begin{array}{l}\text { Multi-Layer Feed } \\
\text { Forward Neural } \\
\text { Networks }\end{array}$ & $86.90 \%$ & $90.90 \%$ & NA & $80.50 \%$ & MRI & $\begin{array}{l}\text { (Al-Naami, } \\
\text { Mallouh, \& } \\
\text { Hafez, 2014) }\end{array}$ & 2014 \\
\hline & & $98.07 \%$ & NA & NA & NA & MRI & $\begin{array}{l}\text { (Jain \& } \\
\text { Mishra) }\end{array}$ & 2013 \\
\hline & $\begin{array}{l}\text { Probabilistic Neural } \\
\text { Network (PNN) }\end{array}$ & $100.00 \%$ & NA & NA & NA & MRI & $\begin{array}{l}\text { (Sapra, Singh, } \\
\text { \& Khurana, } \\
\text { 2013) }\end{array}$ & 2013 \\
\hline & $\begin{array}{l}\text { Self-Organizing } \\
\text { Map(SOM) }\end{array}$ & $98.60 \%$ & NA & NA & NA & MRI & $\begin{array}{c}\text { (Goswami \& } \\
\text { Bhaiya, 2013) }\end{array}$ & 2013 \\
\hline & $\begin{array}{c}\text { Kohonen Neural } \\
\text { Networks }\end{array}$ & $95.00 \%$ & $90 \%$ & NA & $97.00 \%$ & MRI & $\begin{array}{l}\text { (Hemanth, } \\
\text { Anitha, \& } \\
\text { Balas, 2015) }\end{array}$ & 2015 \\
\hline & $\begin{array}{c}\text { Fuzzy Interface } \\
\text { System Feedforward } \\
\text { Neural Network } \\
\text { (FIS+FFNN) } \\
\end{array}$ & $95.66 \%$ & $100 \%$ & NA & $100.00 \%$ & MRI & $\begin{array}{l}\text { (Mahmood \& } \\
\text { Abd-Alsalam, } \\
\text { 2014) }\end{array}$ & 2014 \\
\hline & $\begin{array}{c}\text { Nonlinear } \\
\text { Autoregressive With } \\
\text { Exogenous Neural } \\
\text { Networks(NARXNN) }\end{array}$ & $99.10 \%$ & $100 \%$ & NA & $97.40 \%$ & MRI & $\begin{array}{l}\text { (Al-Naami et } \\
\text { al., 2014) }\end{array}$ & 2014 \\
\hline & $\begin{array}{c}\text { Elman Neural } \\
\text { Network (Elman NN) }\end{array}$ & $98.10 \%$ & $100 \%$ & NA & $95.00 \%$ & MRI & $\begin{array}{l}\text { (Al-Naami et } \\
\text { al., 2014) }\end{array}$ & 2014 \\
\hline
\end{tabular}




\begin{tabular}{|c|c|c|c|c|c|c|c|c|}
\hline \multirow{6}{*}{ 里 } & \multirow{2}{*}{$\begin{array}{c}\text { Backpropagation and } \\
\text { a least Squares } \\
\text { Technique }\end{array}$} & $93.30 \%$ & NA & NA & NA & MRI & $\begin{array}{c}\text { (Hemanth, } \\
\text { Vijila, \& } \\
\text { Anitha, 1995) } \\
\end{array}$ & 1995 \\
\hline & & $89.70 \%$ & $95.60 \%$ & NA & $79.50 \%$ & MRI & $\begin{array}{l}\text { (Al-Naami et } \\
\text { al., 2014) }\end{array}$ & 2014 \\
\hline & \multirow{3}{*}{$\begin{array}{c}\text { Gradient Descent and } \\
\text { Backpropagation } \\
\text { Algorithms }\end{array}$} & $98.67 \%$ & $96.60 \%$ & NA & $95 \%$ & MRI & $\begin{array}{l}\text { (Sharma, } \\
\text { 2012) }\end{array}$ & 2012 \\
\hline & & $94.00 \%$ & $96 \%$ & NA & $93 \%$ & MRI & $\begin{array}{c}\text { (Bhardwaj \& } \\
\text { Siddhu) }\end{array}$ & 2013 \\
\hline & & $94.67 \%$ & $96 \%$ & NA & $93.30 \%$ & MRI & $\begin{array}{c}\text { (Basri, } \\
\text { Othman, \& } \\
\text { Husain, 2013) } \\
\end{array}$ & 2013 \\
\hline & $\begin{array}{l}\text { Backpropagation } \\
\text { Algorithm }\end{array}$ & $89.10 \%$ & NA & NA & NA & MRI & $\begin{array}{l}\text { (Malakooti, } \\
\text { Mousavi, \& } \\
\text { Taba, 2013) }\end{array}$ & 2013 \\
\hline \multirow{4}{*}{ 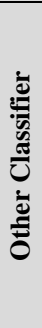 } & Fuzzy K-NN & $99 \%$ & $99.00 \%$ & NA & $98.97 \%$ & MRI & $\begin{array}{l}\text { (Karuppathal } \\
\text { \& Palanisamy, } \\
\text { 2006) } \\
\end{array}$ & 2006 \\
\hline & SVM & $87.00 \%$ & $89.00 \%$ & NA & $79 \%$ & $\begin{array}{l}\text { (MRI) and } \\
\text { Perfusion } \\
\text { MRI } \\
\end{array}$ & $\begin{array}{c}\text { (Zacharaki et } \\
\text { al., 2009) }\end{array}$ & 2009 \\
\hline & Fuzzy SVM & $87.90 \%$ & $86.60 \%$ & NA & $89.20 \%$ & CT & $\begin{array}{l}\text { Dhanalakshmi } \\
\text { \& Rajamani, } \\
\text { 2013) } \\
\end{array}$ & 2013 \\
\hline & K-NN & $70.00 \%$ & NA & NA & NA & MRI & (Mahajani) & 2013 \\
\hline
\end{tabular}

\section{Conclusion:}

Accurate cancer classification is significant in saving the lives of many humans. Despite the use of known diagnostic tools, many researchers are currently interested in using AI classification techniques to classify cancer. This type of study was conducted to compare performance associated with AI classification techniques with cancer classification data, such as ANN techniques, ANFIS, FL, and SVM neural network. The techniques are efficient tools for classifying cancer data. We found that mammograms yielded the most accurate results for breast cancer, achieving $99.73 \%$ with the use of FL simple grid classifier. In lung cancer, PET images presented higher accuracy of 97\%, which was achieved using an SVM classifier, and CT scan obtained the most accurate result of $96.04 \%$, which was achieved using feedforward backpropagation. For brain cancer, MRI scan yielded the most accurate result of $100 \%$, which was achieved using a PPN. Numerous AI techniques can be used to diagnose cancers and obtain different accuracies using different types of data. We found the best classification algorithm and the best medical image type with the highest accuracy for the detection and classification of breast, lung, and brain cancers. 


\section{References:}

1. Ada ${ }^{1}$, R. K. (2013). Early Detection and Prediction of Lung Cancer Survival using Neural Network Classifier: IJAIEM.

2. Al-Daoud, E. (2010). Cancer diagnosis using modified fuzzy network. Universal J. Comput. Sci. \& Engg. Technol, 1(2), 73-78.

3. Al-Naami, B., Mallouh, M. A., \& Hafez, E. A. (2014). Performance Comparison of Adaptive Neural Networks and Adaptive NeuroFuzzy Inference System in Brain Cancer Classification. JJMIE, 8(5).

4. Al-Timemy, A. H., Al-Naima, F. M., \& Qaeeb, N. H. (2009). Probabilistic neural network for breast biopsy classification. Paper presented at the Developments in eSystems Engineering (DESE), 2009 Second International Conference on.

5. Anandgaonkar, G. P., \& Sable, G. S. (2013). Detection and Identification of Brain Tumor in Brain MR Images Using Fuzzy CMeans Segmentation. International Journal of Research in Computer and Communication Engineering Vol. 2 Issue, 10.

6. Azar, A. T., \& El-Said, S. A. (2013). Probabilistic neural network for breast cancer classification. Neural Computing and Applications, 23(6), 1737-1751.

7. Basri, M. A. M., Othman, M. F., \& Husain, A. R. (2013). An Approach to Brain Tumor MR Image Detection and Classification using Neuro Fuzzy. Jurnal Teknologi, 61(2).

8. Bhardwaj, A., \& Siddhu, K. K. An Approach to Medical Image Classification Using Neuro Fuzzy Logic and ANFIS Classifier.

9. Cheng, H. D., Cai, X. P., Chen, X. W., Hu, L. M., \& Lou, X. L. (2003). Computer-aided detection and classification of microcalcifications in mammograms: a survey. Pattern Recognition, 36(12), 2967-2991. doi:10.1016/s0031-3203(03)00192-4

10. Cheng, H. D., \& Cui, M. (2004). Mass lesion detection with a fuzzy neural network. Pattern Recognition, 37(6), 1189-1200. doi:10.1016/j.patcog.2003.11.002

11. Cheng, H. D., Shan, J., Ju, W., Guo, Y. H., \& Zhang, L. (2010). Automated breast cancer detection and classification using ultrasound images: A survey. Pattern Recognition, 43(1), 299-317. doi:10.1016/j.patcog.2009.05.012

12. Cheng, H. D., Shi, X. J., Min, R., Hu, L. M., Cai, X. R., \& Du, H. N. (2006). Approaches for automated detection and classification of masses in mammograms. Pattern Recognition, 39(4), 646-668. doi:10.1016/j.patcog.2005.07.006

13. Dalerba, P., Cho, R. W., \& Clarke, M. F. (2007). Cancer stem cells: models and concepts. Annu. Rev. Med., 58, 267-284. 
14. Darvishi, S., \& Al-Ani, A. (2007). Brain-computer interface analysis using continuous wavelet transform and adaptive neuro-fuzzy classifier. Paper presented at the Engineering in Medicine and Biology Society, 2007. EMBS 2007. 29th Annual International Conference of the IEEE.

15. Dasgupta, A. (2012). Demarcation of brain tumor using modified Fuzzy C-Means. International Journal of Engineering Research and Applications, 2(4), 529-533.

16. Deshmukh, R., \& Khule, R. (2014). Brain Tumor Detection Using Artificial Neural Network Fuzzy Inference System (ANFIS). International Journal of Computer Applications Technology and Research, 3(3), 150-154.

17. Dhanalakshmi, K., \& Rajamani, V. (2013). An Efficient Decision Support System for Diagnosing Brain Tumor Images. International Journal of Fuzzy Systems, 15(2), 254-261.

18. Dhokia, V., Kumar, S., Vichare, P., Newman, S., \& Allen, R. (2008). Surface roughness prediction model for CNC machining of polypropylene. Proceedings of the Institution of Mechanical Engineers, Part B: Journal of Engineering Manufacture, 222(2), 137-157.

19. Doi, K. (2007). Computer-aided diagnosis in medical imaging: Historical review, current status and future potential. Computerized Medical Imaging and Graphics, 31(4-5), 198-211. doi:10.1016/j.compmedimag.2007.02.002

20. Duncan, A., Sacks, S., Melnick, G., Cleland, C. M., Pearson, F. S., \& Coen, C. (2008). Performance of the CJDATS co-occurring disorders screening instruments (CODSIs) among minority offenders. Behavioral sciences \& the law, 26(4), 351.

21. Fatima, B., \& Amine, C. M. (2012). A neuro-fuzzy inference model for breast cancer recognition. International Journal of Computer Science \& Information Technology, 4(5), 163.

22. Fawcett, T. (2006). An introduction to ROC analysis. Pattern recognition letters, 27(8), 861-874.

23. Fazel Zarandi, M. H., Zarinbal, M., \& Izadi, M. (2011). Systematic image processing for diagnosing brain tumors: A Type-II fuzzy expert system approach. Applied Soft Computing, 11(1), 285-294. doi:http://dx.doi.org/10.1016/j.asoc.2009.11.019

24. George, Y. M., Elbagoury, B. M., Zayed, H. H., \& Roushdy, M. I. (2012). Breast Fine Needle Tumor Classification using Neural Networks. International Journal of Computer Science Issues(IJCSI), $9(5)$. 
25. GÖRGEL, P., SERTBAŞ, A., \& UÇAN, O. N. (2012). FEATURE EXTRACTION BASED WAVELET TRANSFORM IN BREAST CANCER DIAGNOSIS USING FUZZY AND NON-FUZZY CLASSIFICATION.

26. Gorynski, K., Safian, I., Gradzki, W., Marszall, M. P., Krysinski, J., Gorynski, S., . . . Bucinski, A. (2014). Artificial neural networks approach to early lung cancer detection. Central European Journal of Medicine, 9(5), 632-641. doi:10.2478/s11536-013-0327-6

27. Goswami, S., \& Bhaiya, L. K. P. (2013). Brain tumour detection using unsupervised learning based neural network. Paper presented at the Communication Systems and Network Technologies (CSNT), 2013 International Conference on.

28. Gould, M. K., Donington, J., Lynch, W. R., Mazzone, P. J., Midthun, D. E., Naidich, D. P., \& Wiener, R. S. (2013). Evaluation of individuals with pulmonary nodules: When is it lung cancer?: Diagnosis and management of lung cancer: American College of Chest Physicians evidence-based clinical practice guidelines. CHEST Journal, 143(5_suppl), e93S-e120S.

29. Hashemi, A., Pilevar, A. H., \& Rafeh, R. (2013). Mass Detection in Lung CT Images Using Region Growing Segmentation and Decision Making Based on Fuzzy Inference System and Artificial Neural Network. International Journal of Image, Graphics and Signal Processing (IJIGSP), 5(6), 16.

30. Hemanth, D. J., Anitha, J., \& Balas, V. E. (2015). Performance Improved Hybrid Intelligent System for Medical Image Classification. Paper presented at the Proceedings of the 7th Balkan Conference on Informatics Conference.

31. Hemanth, D. J., Vijila, C. K. S., \& Anitha, J. (1995). Application of Neuro-Fuzzy Model for MR Brain Tumor Image.

32. Hiran, K. K., \& Doshi, R. (2013). An artificial neural network approach for brain tumor detection using digital image segmentation. Brain, 2(5).

33. Huang, G. B., Chen, L., \& Siew, C. K. (2006). Universal approximation using incremental constructive feedforward networks with random hidden nodes. Ieee Transactions on Neural Networks, 17(4), 879-892. doi:10.1109/tnn.2006.875977

34. Huang, Z. X. (1998). Extensions to the k-means algorithm for clustering large data sets with categorical values. Data Mining and Knowledge Discovery, 2(3), 283-304. doi:10.1023/a:1009769707641

35. Ibrahim, W. H., Osman, A. A. A., \& Mohamed, Y. I. (2013). MRI Brain Image Classification using neural networks. Paper presented at 
the Computing, Electrical and Electronics Engineering (ICCEEE), 2013 International Conference on.

36. Jain, R., \& Abraham, A. (2004). A comparative study of fuzzy classification methods on breast cancer data. Australasian Physics \& Engineering Sciences in Medicine, 27(4), 213-218.

37. Jain, S., \& Mishra, S. ANN Approach Based On Back Propagation Network and Probabilistic Neural Network to Classify Brain Cancer. Paper presented at the ases.

38. Jain, S., \& Mishra, S. (2013). ANN Approach Based On Back Propagation Network and Probabilistic Neural Network to Classify Brain Cancer. Paper presented at the ases.

39. Janghel, R., Shukla, A., Tiwari, R., \& Kala, R. (2010). Breast cancer diagnosis using artificial neural network models. Paper presented at the Information Sciences and Interaction Sciences (ICIS), 2010 3rd International Conference on.

40. Joshi, D. M., Rana, N., \& Misra, V. (2010). Classification of brain cancer using artificial neural network. Paper presented at the Electronic Computer Technology (ICECT), 2010 International Conference on.

41. Jung, I.-S., Thapa, D., \& Wang, G.-N. (2005). Neural Network Based Algorithms for Diagnosis and Classification of Breast Cancer Tumor. In Y. Hao, J. Liu, Y. Wang, Y.-m. Cheung, H. Yin, L. Jiao, J. Ma, \& Y.-C. Jiao (Eds.), Computational Intelligence and Security (Vol. 3801, pp. 107-114): Springer Berlin Heidelberg.

42. Kanakatte, A., Mani, N., Srinivasan, B., \& Gubbi, J. (2008). Pulmonary tumor volume detection from positron emission tomography images. Paper presented at the BioMedical Engineering and Informatics, 2008. BMEI 2008. International Conference on.

43. Karameh, F. N., \& Dahleh, M. A. (2000). Automated classification of EEG signals in brain tumor diagnostics. Paper presented at the American Control Conference, 2000. Proceedings of the 2000.

44. Karuppathal, R., \& Palanisamy, V. (2006). FUZZY BASED AUTOMATIC DETECTION AND CLASSIFICATION APPROACH FOR MRI-BRAIN TUMOR.

45. Kathalkar, A. A., Kawitkar, R., \& Chopade, A. (2013). Artificial Neural Network based Brain Cancer Analysis and Classification. International Journal of Computer Applications, 66(10).

46. Kharat, K. D., Kulkarni, P. P., \& Nagori, M. (2012). Brain tumor classification using neural network based methods. International Journal of Computer Science and Informatics, 1(4). 
47. Kumar, G. J., \& Kumar, G. V. (2008). Biological Early Brain Cancer Detection Using Artificial Neural Networks. Paper presented at the Artificial Intelligence and Pattern Recognition.

48. Kuruvilla, J., \& Gunavathi, K. (2014). Lung cancer classification using neural networks for CT images. Computer Methods and Programs in Biomedicine, 113(1), 202-209. doi:http://dx.doi.org/10.1016/j.cmpb.2013.10.011

49. Lichman, M. ((2013)). UCI Machine Learning Repository from Irvine, CA: University of California, School of Information and Computer Science [http://archive.ics.uci.edu/ml]

50. Madero Orozco, H., Vergara Villegas, O. O., de Jesus Ochoa Dominguez, H., \& Cruz Sanchez, V. G. (2013). Lung Nodule Classification in CT Thorax Images Using Support Vector Machines. Paper presented at the Artificial Intelligence (MICAI), 2013 12th Mexican International Conference on.

51. Madhusudhanareddy, P., \& Prabha, I. S. (2013). Novel Approach In Brain Tumor Classification Using Artificial Neural Networks.

52. Mahajani, P. P. P. Detection and Classification of Brain Tumor in MRI Images.

53. Mahmood, A. F., \& Abd-Alsalam, A. M. (2014). Automatic Brain MRI Slices Classification Using Hybrid Technique. Al-Rafidain Engineering Journal, 22(3).

54. Malakooti, D. M. V., Mousavi, S. A., \& Taba, D. N. H. (2013). MRI Brain Image Segmentation Using Combined Fuzzy Logic and Neural Networks for Tumor Detection. Journal of Academic and Applied Studies, 3(5).

55. Memarian, N., Alirezaie, J., \& Babyn, P. (2006). Computerized detection of lung nodules with an enhanced false positive reduction scheme. Paper presented at the Image Processing, 2006 IEEE International Conference on.

56. Miranda, G. H. B., \& Felipe, J. C. (2014). Computer-aided diagnosis system based on fuzzy logic for breast cancer categorization. Computers in biology and medicine.

57. Murino, V., Puppo, E., Sona, D., Cristani, M., \& Sansone, C. (2015). New Trends in Image Analysis and Processing--ICIAP 2015 Workshops: ICIAP 2015 International Workshops, BioFor, CTMR, RHEUMA, ISCA, MADiMa, SBMI, and QoEM, Genoa, Italy, September 7-8, 2015, Proceedings (Vol. 9281): Springer.

58. Nalbalwar, R., Majhi, U., Patil, R., \& Gonge, S. Detection of Brain Tumor by using ANN. image, 2(3), 7.

59. National Cancer Institute (2012). Cancer Statistics. Retrieved from http://www.cancer.gov/about-cancer/what-is-cancer/statistics 
60. Nehemiah, H. K., \& Kannan, A. (2006). An intelligent system for lung cancer diagnosis from chest radiographs. International Journal of Soft Computing, 1(2), 133-136.

61. Onan, A. (2015). A fuzzy-rough nearest neighbor classifier combined with consistency-based subset evaluation and instance selection for automated diagnosis of breast cancer. Expert Systems with Applications, $\quad$ 42(20), 6844-6852. doi:http://dx.doi.org/10.1016/j.eswa.2015.05.006

62. Othman, M. F., \& Basri, M. A. M. (2011). Probabilistic neural network for brain tumor classification. Paper presented at the Intelligent Systems, Modelling and Simulation (ISMS), 2011 Second International Conference on.

63. Padmapriya, A., \& Maragatham, K. S. C. (2013). Priority Based Apriori Algorithm For Cancer Prediction Using Fuzzy Classification. Paper presented at the International Journal of Engineering Research and Technology.

64. Peng, Y. H., Jianmin, J., \& Wu, Z. Q. (2009). Computational Intelligence on Medical Imaging with Artificial Neural Networks Computational Intelligence in Medical Imaging (pp. 1-26): Chapman and Hall/CRC.

65. Pereira, C. S., Alexandre, L. A., Mendonça, A. M., \& Campilho, A. (2006). A multiclassifier approach for lung nodule classification Image Analysis and Recognition (pp. 612-623): Springer.

66. Raad, A., Kalakech, A., \& Ayache, M. (2012). Breast cancer classification using neural network approach: MLP and RBF. Networks, 7(8), 9.

67. Sapra, P., Singh, R., \& Khurana, S. (2013). Brain Tumor Detection Using Neural Network. International Journal of Science and Modern Engineering (IJISME) ISSN, 2319-6386.

68. Schaefer, G., Nakashima, T., Zavisek, M., Yokota, Y., Drastich, A., \& Ishibuchi, H. (2007). Breast cancer classification using statistical features and fuzzy classification of thermograms. Paper presented at the Fuzzy Systems Conference, 2007. FUZZ-IEEE 2007. IEEE International.

69. Schaefer, G., Nakashima, T., Zavisek, M., Yokota, Y., Drastich, A., Ishibuchi, H., \& Ieee. (2007). Breast cancer classification using statistical features and fuzzy classification of thermograms 2007 Ieee International Conference on Fuzzy Systems, Vols 1-4 (pp. 11011105). New York: Ieee, Electron Devices Soc \& Reliability Group.

70. Seema Singh , S. H., Harini J and Surabhi B.R. (2014). An Efficient Neural Network Based System for Diagnosis of Breast Cancer 
International Journal of Computer Science and information Technologies,

71.5 (((3)), 4354-4360.

72. Sharma, M. (2012). Artificial Neural Network Fuzzy Inference System (ANFIS) For Brain Tumor Detection. arXiv preprint arXiv:1212.0059.

73. Singh, B. K., Verma, K., \& Thoke, A. (2015). Adaptive Gradient Descent Backpropagation for Classification of Breast Tumors in Ultrasound Imaging. Procedia Computer Science, 46, 1601-1609.

74. Singh, S., Saini, S., \& Singh, M. (2012). Cancer detection using adaptive neural network. International Journal of Advancements in Research \& Technology, 1(4), 93-97.

75. Sivakumar, S., \& Chandrasekar, C. (2013). Lung nodule detection using fuzzy clustering and support vector machines. International Journal of Engineering and Technology (IJET), 5(1), 179-185.

76. Song, D., Zhukov, T. A., Markov, O., Qian, W., \& Tockman, M. S. (2012). Prognosis of stage I lung cancer patients through quantitative analysis of centrosomal features. Paper presented at the Biomedical Imaging (ISBI), 2012 9th IEEE International Symposium on.

77. Soria, D., Garibaldi, J. M., Green, A. R., Powe, D. G., Nolan, C. C., Lemetre, C., . . . Ellis, I. O. (2013). A quantifier-based fuzzy classification system for breast cancer patients. Artificial intelligence in medicine, 58(3), 175-184.

78. SubbaRao, M., Revanth, B., \& UdayKumar, D. (2013). Mri Brain Image Classification Using Probabilistic Neural Network And Tumor Detection Using Clustering Technique. Paper presented at the International Journal of Engineering Research and Technology.

79. Swathi, S., Rizwana, S., Babu, G. A., Kumar, P. S., \& Sarma, P. Classification Of Neural Network Structures For Brea St Cancer Diagnosis.

80. Taher, F., \& Sammouda, R. (2011). Lung cancer detection by using artificial neural network and fuzzy clustering methods. Paper presented at the GCC Conference and Exhibition (GCC), 2011 IEEE.

81. Taher, F., Werghi, N., \& Al-Ahmad, H. (2012). Bayesian classification and artificial neural network methods for lung cancer early diagnosis. Paper presented at the Electronics, Circuits and Systems (ICECS), 2012 19th IEEE International Conference on.

82. Tariq, A., Akram, M. U., \& Javed, M. Y. (2013). Lung Nodule Detection in CT images using neuro fuzzy classifier. Paper presented at the Computational Intelligence in Medical Imaging (CIMI), 2013 IEEE Fourth International Workshop on. 
83. Ubaidillah, S. H. S. A., Sallehuddin, R., \& Ali, N. A. (2013). Cancer Detection Using Aritifical Neural Network and Support Vector Machine: A Comparative Study. Jurnal Teknologi, 65(1).

84. Übeyli, E. D. (2009). Adaptive neuro-fuzzy inference systems for automatic detection of breast cancer. Journal of medical systems, 33(5), 353-358.

85. Zacharaki, E., Wang, S., Chawla, S., Yoo, D. S., Wolf, R., Melhem, E. R., \& Davatzikos, C. (2009). MRI-based classification of brain tumor type and grade using SVM-RFE. Paper presented at the Biomedical Imaging: From Nano to Macro, 2009. ISBI'09. IEEE International Symposium on.

86. Zhou, C., Wu, Y.-L., Chen, G., Feng, J., Liu, X.-Q., Wang, C., . . . Ren, S. (2011). Erlotinib versus chemotherapy as first-line treatment for patients with advanced EGFR mutation-positive non-small-cell lung cancer (OPTIMAL, CTONG-0802): a multicentre, open-label, randomised, phase 3 study. The lancet oncology, 12(8), 735-742.

87. Zhou, Z.-H., Jiang, Y., Yang, Y.-B., \& Chen, S.-F. (2002). Lung cancer cell identification based on artificial neural network ensembles. Artificial Intelligence in Medicine, 24(1), 25-36. doi:http://dx.doi.org/10.1016/S0933-3657(01)00094-X 